\title{
Chemical Characteristics of Irrigated Ultisol with Dairy Effluent Dilutions
}

\author{
Andrezza Grasielly Costa ${ }^{1}$, Sandra Maria Campos Alves ${ }^{2}$, \\ Rafael Oliveira Batista ${ }^{1}$ (D) Hérick Claudino Mendes ${ }^{1}$, \\ Danilo Isac Maia de Souza ${ }^{1}$ \\ ${ }^{1}$ Universidade Federal Rural do Semi-Arido - UFERSA, Mossoró/RN, Brasil \\ ${ }^{2}$ Instituto Federal de Educação Ciência e Tecnologia do Rio Grande do Norte, Canguaretama/RN, Brasil
}

\begin{abstract}
The objective of this work was to analyze the changes in the chemical attributes of an Ultisol irrigated with different dairy effluent dilutions. The experiment was set up using a randomized block design with five dilutions of dairy effluent (DE) in public water supply (PWS) (T1 - only PWS, T2 - 10\% of DE plus PWS, T3 - 20\% of DE plus PWS, T4 - 30\% of DE plus PWS, and T5 - 40\% of DE plus PWS). Soil samples were collected at five depths to quantify the attributes of $\mathrm{pH}$, organic matter $(\mathrm{OM})$, potassium $(\mathrm{K})$, phosphorus $(\mathrm{P})$ and electrical conductivity of the soil saturation extract (ECss). No significant effects of dairy effluent dilutions were found in altering the $\mathrm{pH}, \mathrm{OM}$ and $\mathrm{K}^{+}$values of the Ultisol after 240 days of application. However, there was a significant increase of $\mathrm{P}$ in T4, and of ECss mainly in the 0.10 to $0.20 \mathrm{~m}$ layer of T5.
\end{abstract}

Keywords: reuse, industrial wastewater, soil quality. 


\section{INTRODUCTION}

Food industries demand large amounts of water for productive processes and operational needs, thereby generating a high amount of effluents which require treatment before being released into the environment. These effluents are characterized by high levels of Biochemical Oxygen Demand and Chemical Oxygen Demand (Sarkar et al., 2006; Farizoglu \& Uzuner, 2011).

Toze (2006) emphasizes the benefits of using this water for irrigation, among them the use of water in addition to using the present nutrients, generating positive impacts on the environment; for this reason, making use of effective agricultural practices is essential, taking into account the attributes present in these effluents.

Among the food processing industries, the dairy industry stands out in relation of being a potential pollutant of water bodies, considering that milk beneficiation/processing increases the pollutant load in wastewaters (Chaiudhari \& Dhoble, 2010; Matos et al., 2010; Demirel et al., 2005; Qasim \& Mane, 2013).

The contribution of nutrients and organic matter contained in the effluents are extremely important for the development of plants that require nutrients, especially during their development. Due to their extraction capacity, plants function by removing these constituents, maintaining soil fertility levels (Mohammad Rusan et al., 2007; Matos et al., 2010).

Thus, the use of dairy effluents favor the development of spineless Mandacaru (Cereus hildmannianus) by providing organic matter, improving soil structure, increasing nutrient supply and soil water retention capacity. DairyCatch (2006) emphasizes that the application of wastewater on the soil facilitates the slow release of nutrients to the plants.

The production of Cereus hildmannianus represents a viable alternative for animal feeding in the Brazilian semiarid, since it does not require an excessive use of water, as well as having a low production cost and higher biomass protein content than other forages (Cavalcanti \& Resende, 2006).

According to Santos et al. (2013), the application of $400 \mathrm{~m}^{3} \mathrm{ha}^{-1}$ of dairy effluent resulted in an increase in the organic carbon, potassium, phosphorus and calcium contents of the soil, positively affecting fertility.
The authors also emphasize that the use of dairy effluents presents a partial substitution potential of phosphate fertilization and total potassium fertilization.

Mohammad Rusan et al. (2007) highlight that proper management of wastewater, in addition to periodic monitoring of soil fertility and effluent quality, should guarantee success in reuse practice.

In this context, the objective of this study was to analyze the effects of applying dairy effluent dilutions in public water supply on the alterations of hydrogenation potential, conductivity of the saturation extract, organic matter, phosphorus and potassium along the profile of a Ultisol in Mossoró-RN, Brazil.

\section{MATERIAL AND METHODS}

This study was developed at the Experimental Unit of Water Reuse (UERA) which occupies $770 \mathrm{~m}^{2}$ $(20 \mathrm{~m} \times 38.5 \mathrm{~m})$, centralized in the Federal Rural University of the Semi-Arid (UFERSA), Mossoró-RN $\left(5^{\circ} 12^{\prime} 29,32^{\prime \prime} S\right.$ and $\left.37^{\circ} 19^{\prime} 06,12^{\prime \prime} \mathrm{W}\right)$.

According to the Köppen-Geiger classification, the region has a BSh' type climate, being hot and dry with a rainy season concentrated between May and July and intense drought from September to December, with average annual rainfall of less than $650 \mathrm{~mm}$ and a mean annual temperature of more than $26.5^{\circ} \mathrm{C}$ (Alvares et al., 2014).

According to the Brazilian Soil Classification System (EMBRAPA, 2013), the soil of the experimental area is classified as Ultisol. Table 1 shows the physicochemical attributes of this soil before applying diluted dairy effluent.

An experimental area for the production of Cereus hildmannianus irrigated with dairy effluent dilutions in the public water supply was set up at UERA. The effluent was collected from an aerated facultative pond of a dairy company in the municipality of Mossoró-RN, Brazil. The dairy effluent was generated from processing pasteurized milk, dairy beverages, dulce de leche (caramel milk), cheese curd (requeijão), coalho cheese, Minas frescal cheese and clarified butter (manteiga-do-sertão), and from sanitation of the farm (Marques et al., 2016).

Transportation of the dairy effluent from the farm to UERA was performed in five 20 - $\mathrm{L}$ impermeable 
reservoirs, always transported on the irrigating day of the Cereus hildmannianus in order to minimize depriving of the liquid residue.

The public water supply came from a well managed by Companhia de Águas e Esgotos do Rio Grande do Norte (CAERN) and was stored in an impermeable reservoir of $16 \mathrm{~m}^{3}$.

An experimental area occupying $49 \mathrm{~m}^{2}$ was reserved at UERA, where 25 plots each corresponding to $1.0 \times 1.0 \mathrm{~m}$ $\left(1.0 \mathrm{~m}^{2}\right)$ in dimension with $0.50 \mathrm{~m}$ between the blocks and plots were delimited, as shown in Figure 1.
The experiment was set up in a completely randomized block design, in which the factors of dairy effluent dilutions in public water supply and soil depths were studied, according to the recommendations of Coelho et al. (2015a, b).

The following components were used for application of public water supply, in accordance with the recommendations by Coelho et al. (2015a, b): a) A $16 \mathrm{~m}^{3}$ concrete reservoir; b) a 0.5 -cv motor-pump set with a screen filter, with $130 \mu \mathrm{m}$ openings; c) a PVC mainline with $32 \mathrm{~mm}$ of diameter; and d) 20 side lines with non-compensating

Table 1. Physical-chemical attributes of the Ultisol before application of dairy effluent dilutions in the public water supply.

\begin{tabular}{|c|c|c|c|c|c|c|c|c|c|c|}
\hline \multirow{2}{*}{$\begin{array}{c}\text { Depth } \\
(\mathbf{m})\end{array}$} & $\rho_{\mathrm{s}}$ & $\rho_{\mathrm{p}}$ & Sa & Si & $\mathrm{Cl}$ & \multirow{2}{*}{$\mathbf{p H}$} & \multirow{2}{*}{$\frac{\text { ECss }}{\mathrm{dS} \mathrm{m}^{-1}}$} & \multirow{2}{*}{$\frac{\mathrm{OM}}{\mathrm{g} \mathbf{d m}^{-3}}$} & \multirow{2}{*}{\multicolumn{2}{|c|}{ 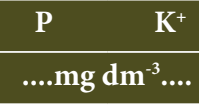 }} \\
\hline & $\mathrm{g} \mathrm{cm}^{-3}$ & $\mathrm{~g} \mathrm{~cm}^{-3}$ & ..... & $\mathrm{kg} \mathrm{kg}^{-1}$ & $\ldots$. & & & & & \\
\hline 0 to 0.10 & 1.81 & 2.64 & 0.83 & 0.09 & 0.08 & 6.75 & 0.59 & 20.78 & 35.31 & 115.04 \\
\hline 0.10 to 0.20 & 1.70 & 2.44 & 0.83 & 0.09 & 0.08 & 6.79 & 0.48 & 24.46 & 28.89 & 92.66 \\
\hline 0.20 to 0.30 & 1.28 & 2.41 & 0.81 & 0.08 & 0.11 & 7.08 & 0.31 & 14.71 & 18.93 & 134.84 \\
\hline 0.30 to 0.40 & 1.96 & 2.38 & 0.71 & 0.12 & 0.17 & 7.08 & 0.18 & 14.16 & 11.29 & 194.22 \\
\hline 0.40 to 0.50 & 1.86 & 2.45 & 0.63 & 0.07 & 0.30 & 7.13 & 0.13 & 13.24 & 8.32 & 184.32 \\
\hline Mean & 1.72 & 2.46 & 0.76 & 0.09 & 0.15 & 6.97 & 0.34 & 17.47 & 20.55 & 144.22 \\
\hline
\end{tabular}

Note: $\rho_{\mathrm{s}}$ - Specific soil mass determined by the volumetric ring method; $\rho_{\mathrm{p}}$ - Specific mass of soil particles determined by volumetric flask method; $\mathrm{Sa}$, Si and $\mathrm{Cl}$ - Sand, silt and clay determined by the pipette method; $\mathrm{pH}$ - Potential of hydrogen in water (ratio 1:2,5); ECss - Electrical conductivity of the soil saturation extract; OM - Organic matter determined by the Walkley-Black method; $\mathrm{P}$ - Available phosphorus extracted by the Mehlich-1 method; and $\mathrm{K}^{+}$- Exchangeable potassium extracted by the Mehlich-1 method, according to EMBRAPA technical recommendations (Silva, 2009).

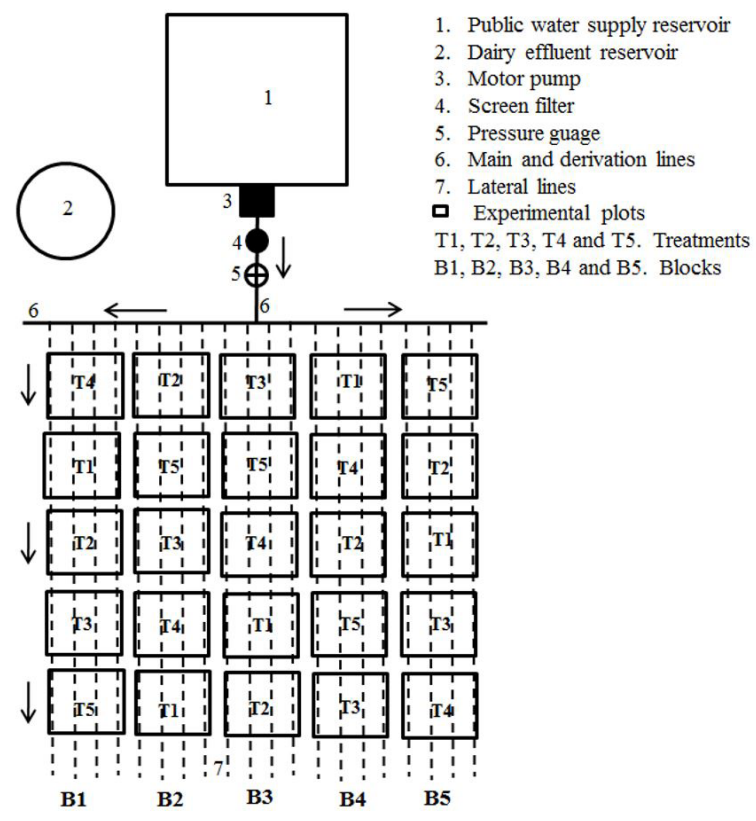

Figure 1. Experimental area schematic adapted from Coelho et al. (2015a, b). Note: 1 - Public water supply reservoir; 2 - Dairy effluent reservoir; 3 - Motor pump; 4 - Screen filter; 5 - Pressure gauge; 6 - Main and derivation lines; 7 - Lateral lines; $\square$ Experimental plots; T1, T2, T3, T4 and T5 - Treatments; and B1, B2, B3, B4 and B5 - Blocks. 
emitters of $2.0 \mathrm{~L} \mathrm{~h}^{-1}$ and $0.30 \mathrm{~m}$ spacing between the emitters.

The irrigation system was operated with water from the public supply during the experimental period at an operating pressure of $100 \mathrm{kPa}$, using a glycerin manometer graduated from 0 to $400 \mathrm{kPa}$ with an accuracy of $10 \mathrm{kPa}$.

The dairy effluent application followed the guidelines proposed by Coelho et al. (2015a, b): a) Mixing the effluent inside a reservoir to homogenize the fluid, thus minimizing the sedimentation effect; b) Measuring the specific amount with a $1 \mathrm{~L}$ graduated test tube; c) Transferring the measured amount to a watering can; and d) Applying the effluent directly into the soil within each plot using a watering can, minimizing direct contact of the liquid with the plants (Cereus hildmannianus).

The Cereus hildmannianus were planted on April $18^{\text {th }}$, 2015; four $0.25 \mathrm{~m}$ long seedlings were planted per plot, at a depth of $0.15 \mathrm{~m}$ in the ground and spaced at 0.50 m. No liming, mineral foundation, or topdressing fertilization were performed during the crop's cycle, based on the methodology presented by Coelho et al. (2015a, b).

The treatments were applied based on the EPA criteria (EPA, 1981) presented by Equation 1, and the water requirements for the crops were: T1 - only public water supply (PWS); T2 - 0.1 x loading rate (Lw) of the EPA plus PWS; T3 - 0.2 x EPA's Lw plus PWS; T4 - 0.3 x EPA's Lw plus PWS; and T5 - 0.4 x EPAs Lw plus PWS.

$L w=\frac{C p \cdot(P R-E T)+10 U}{(1-f) C n-C p}$

In which:

$\mathrm{L}_{\mathrm{W}}$ - annual allowable loading rate based on nitrogen limits, cm year ${ }^{-1}$;

$\mathrm{Cp}$ - nitrogen concentration in percolating water, $\mathrm{mg} \mathrm{L}^{-1}$;

PR - local precipitation rate, $\mathrm{cm}$ year ${ }^{-1}$;
ET - crop evapotranspiration rate on site, $\mathrm{cm}$ year $^{-1}$;

$\mathrm{U}$ - nitrogen uptake by the crop, $\mathrm{kg} \mathrm{ha}^{-1}$ year $^{-1}$;

$\mathrm{Cn}$ - nitrogen concentration in the wastewater, $\mathrm{mg} \mathrm{L}^{-1}$; and

$\mathrm{f}$ - fraction of nitrogen removed by denitrification and volatilization.

The physicochemical characterization of dairy effluent and public water supply was carried out monthly during the experimental period by collection of three composite samples from April to December 2015. Table 2 shows the mean values for the physicochemical characteristics of dairy effluent and public water supply.

For treatments $\mathrm{T} 1$ to $\mathrm{T} 5$, the public water supply application was carried out every 15 days, from the planting of the grass on April 18 ${ }^{\text {th }}, 2015$ until the end of the experiment on December $18^{\text {th }}, 2015$. However, the dairy effluent application took place starting on June $1^{\text {st }}, 2015$. At the end of 240 days all treatments received a $227.14 \mathrm{~mm}$ of dairy effluent diluted in the water supply.

In order to evaluate soil quality samples were collected from 0 to $0.10 \mathrm{~m}, 0.10$ to $0.20 \mathrm{~m}$, 0.20 to $0.30 \mathrm{~m}, 0.30$ to $0.40 \mathrm{~m}$ and 0.40 to $0.50 \mathrm{~m}$ according to recommendations by Lima et al. (2013) with the aid of a Dutch auger, before and after 240 days applying the dairy effluent dilutions.

Four simple samples were collected from each layer within the wet range formed by the drip irrigation system, obtaining a depth sample from each one of the 25 plots of the experiment.

The following chemical characteristics of the soil were determined in the Laboratory of Water, Soil and Plant Analysis (LASAP) of UFERSA: potential of hydrogen $(\mathrm{pH})$, electrical conductivity of the soil saturation extract (ECss), organic matter (OM), available phosphorus (P) and exchangeable potassium (K) according to EMBRAPA technical criteria (Silva, 2009).

Table 2. Mean values of the physicochemical characteristics of dairy effluent (DE) and public water supply (PWS) during the experimental period.

\begin{tabular}{|c|c|c|c|c|c|c|c|}
\hline $\begin{array}{l}\text { Type of } \\
\text { fluid }\end{array}$ & pH & $\begin{array}{c}\mathrm{EC} \\
\left(\mathrm{dS} \mathbf{~ m}^{-1}\right)\end{array}$ & $\begin{array}{l}\mathrm{BOD}_{5}{ }^{20} \\
\left(\mathrm{mg} \mathrm{L}^{-1}\right)\end{array}$ & $\begin{array}{c}\mathrm{PO}_{4}^{-} \\
\left(\mathrm{mg} \mathrm{L}^{-1}\right)\end{array}$ & $\begin{array}{c}\mathrm{K}^{+} \\
\left(\mathrm{mmol}_{\mathrm{c}} \mathrm{L}^{-1}\right)\end{array}$ & $\begin{array}{c}\mathrm{HCO}_{3}^{-} \\
\left(\mathrm{mmol}_{\mathrm{c}}^{\left.-\mathrm{L}^{-1}\right)}\right.\end{array}$ & $\begin{array}{c}\mathrm{Cl}^{-} \\
\left(\mathrm{mmol}_{c}^{-1} \mathrm{~L}^{-1}\right)\end{array}$ \\
\hline $\mathrm{DE}$ & 7.80 & 4.60 & 1504 & 39 & 20.97 & 15.63 & 40.00 \\
\hline PWS & 8.30 & 0.62 & NP & NP & 2.41 & 4.00 & 5.20 \\
\hline
\end{tabular}

Note: NP - Not performed; EC - Electrical conductivity; $\mathrm{BOD}_{5}{ }^{20}$ - Biochemical oxygen demand; $\mathrm{PO}_{4}^{-}$- Phosphate; $\mathrm{K}^{+}$- Potassium; $\mathrm{HCO}_{3}^{-}$- Bicarbonates; and $\mathrm{Cl}^{-}$- Chlorides. 
Data on soil characteristics were submitted to analysis of variance using the computer program SISVAR (Systems for Analysis of Variance) developed by Ferreira (2011). In addition, the Tukey test and orthogonal contrasts test for multiple comparison of averages were also performed.

The proposed orthogonal contrasts were: 1 ) treatment $\mathrm{T} 5$ versus other treatments (T1, T2, T3 and T4); 2) treatment 4 versus treatments T1, T2 and T3); 3) treatment $T 3$ versus treatments $T 1$ and $T 2$; and 4) treatment $\mathrm{T} 2$ versus treatment $\mathrm{T} 1$. The combinations of the contrasts with the treatment averages were expressed as follows:

$$
\begin{aligned}
& \mathrm{C} 1=12 \mathrm{~m} 1+12 \mathrm{~m} 2+8 \mathrm{~m} 3+10 \mathrm{~m} 4-42 \mathrm{~m} 5 \\
& \mathrm{C} 2=30 \mathrm{~m} 1+30 \mathrm{~m} 2+20 \mathrm{~m} 3-80 \mathrm{~m} 4 \\
& \mathrm{C} 3=6 \mathrm{~m} 1+6 \mathrm{~m} 2-12 \mathrm{~m} 3 \\
& \mathrm{C} 4=6 \mathrm{~m} 1-6 \mathrm{~m} 2
\end{aligned}
$$

\section{RESULTS AND DISCUSSION}

Table 3 presents the mean values and Tukey test, coefficient of variation, standard error and probability, as well as the contrasts of the applied treatment averages after 240 days of soil irrigation.
In Table 3, it was observed that dairy effluent dilutions had a significant effect on the ECss attribute due to the high EC of the wastewater in relation to the public water supply (Table 2), which increased salts in the soil layers, specifically in deeper ones with higher clay content, as presented in Table 1. These results corroborate those found by Coelho et al. (2015a) who applied leaching landfill dilutions to Ultisol for 120 days.

According to NSW (2010), excess salts can restrict the plant growth, thus classifying ECss as very low $\left(<0.65 \mathrm{dS} \mathrm{m}^{-1}\right)$ for all treatments. However, soil salinity levels need to be monitored and controlled, aiming at minimizing future potential impacts on its structure and surface.

According to the analysis of the contrasts, only C1 was significant with $1 \%$ probability for the $\mathrm{EC}_{\mathrm{SS}}$ variable, indicating that the mean ECss for treatment T5 differs from the sum of the means from other treatments. Due to the higher increase of salts added in the soil by the effluent of this treatment.

In relation to the $\mathrm{pH}, \mathrm{OM}, \mathrm{P}$ and $\mathrm{K}^{+}$attributes, no significant effects of the dairy effluent dilutions were

\begin{tabular}{|c|c|c|c|c|c|}
\hline \multirow{3}{*}{ Treatments } & \multicolumn{5}{|c|}{ Chemical characteristics of the soil } \\
\hline & \multirow{2}{*}{$\mathbf{p H}$} & ECss $^{(1)}$ & $\mathrm{OM}$ & $\mathbf{P}$ & $\mathbf{K}$ \\
\hline & & dS $\mathbf{m}^{-1}$ & $\mathrm{~g} \mathrm{dm}^{-3}$ & \multicolumn{2}{|c|}{.........mg dm ${ }^{-3} \ldots . . . . .}$. \\
\hline $\mathrm{T} 1$ & 6.68 & $0.18 \mathrm{a}$ & 6.84 & 23.53 & 155.79 \\
\hline $\mathrm{T} 2$ & 6.74 & $0.24 \mathrm{a}$ & 8.23 & 21.37 & 186.64 \\
\hline T3 & 6.90 & $0.33 \mathrm{ab}$ & 6.13 & 24.50 & 198.57 \\
\hline $\mathrm{T} 4$ & 6.93 & $0.33 \mathrm{ab}$ & 5.49 & 37.41 & 221.28 \\
\hline T5 & 6.95 & $0.59 b$ & 8.30 & 19.41 & 247.45 \\
\hline Mean & 6.84 & 0.33 & 6.99 & 25.24 & 201.94 \\
\hline CV $(\%)$ & 3.85 & 41.97 & 37.40 & 49.22 & 32.64 \\
\hline Standard error & 0.118 & 0.063 & 1.171 & 5.556 & 29.480 \\
\hline Probability & $0.4086^{\mathrm{NS}}$ & $0.0030^{*}$ & $0.3726^{\mathrm{NS}}$ & $0.2166^{\mathrm{NS}}$ & $0.2828^{\mathrm{NS}}$ \\
\hline \multicolumn{6}{|c|}{ Probability of the contrasts (Decimal) } \\
\hline Contrast $\mathrm{C}_{1: \mathrm{T} 5 \mathrm{Vs}(\mathrm{T} 1+\mathrm{T} 2+\mathrm{T} 3+\mathrm{T} 4)}$ & $0.2786^{\mathrm{NS}}$ & $0.0002^{\star *}$ & $0.2646^{\mathrm{NS}}$ & $0.2782^{\mathrm{NS}}$ & $0.0926^{\mathrm{NS}}$ \\
\hline Contrast $\mathrm{C}_{2: \mathrm{T} 4 \mathrm{Vs}(\mathrm{T} 1+\mathrm{T} 2+\mathrm{T} 3)}$ & $0.3321^{\mathrm{NS}}$ & $0.2206^{\mathrm{NS}}$ & $0.2283^{\mathrm{NS}}$ & $0.0393^{\star}$ & $0.2240^{\mathrm{NS}}$ \\
\hline Contrast $\mathrm{C}_{3: \mathrm{T3} \mathrm{Vs}(\mathrm{T} 1+\mathrm{T} 2)}$ & $0.1432^{\mathrm{NS}}$ & $0.1350^{\mathrm{NS}}$ & $0.3417^{\mathrm{NS}}$ & $0.7670^{\mathrm{NS}}$ & $0.4596^{\mathrm{NS}}$ \\
\hline Contrast $\mathrm{C}_{4: \mathrm{T} 2 \mathrm{Vs} \mathrm{T} 1}$ & $0.7588^{\mathrm{NS}}$ & $0.5228^{\mathrm{NS}}$ & $0.4174^{\mathrm{NS}}$ & $0.7871^{\mathrm{NS}}$ & $0.4700^{\mathrm{NS}}$ \\
\hline
\end{tabular}
observed. Bolzani et al. (2012) analyzed the effects of applying residual doses of wastewater from pig

Table 3. Chemical characteristics of the Ultisol irrigated with dairy effluent dilutions in the public water supply.

Note: T1 - Only public water supply (PWS), T2 - 0.1 x EPA Lw plus PWS, T3 - 0.2 x EPA Lw plus PWS, T4 - 0.3 x EPA's Lw plus PWS, and T5 - 0.4 x EPA Lw plus PWS; pH - Potential of hydrogen; ECss - Electrical conductivity of the soil saturation extract; $\mathrm{OM}$ - Organic matter; P - Available phosphorus; and $\mathrm{K}^{+}$- Exchangeable potassium; $\mathrm{C} 1=12 \mathrm{~m} 1+12 \mathrm{~m} 2+8 \mathrm{~m} 3+10 \mathrm{~m} 4-42 \mathrm{~m} 5$; $\mathrm{C} 2=30 \mathrm{~m} 1+30 \mathrm{~m} 2+20 \mathrm{~m} 3-80 \mathrm{~m} 4 ; \mathrm{C} 3=6 \mathrm{~m} 1+6 \mathrm{~m} 2-12 \mathrm{~m} 3 ; \mathrm{C} 4=6 \mathrm{~m} 1-6 \mathrm{~m} 2$; ${ }^{(1)}$ Means followed by the same letters in the column do not differ statistically by the Tukey test at $5 \%$ probability; ${ }^{* *}$ and ${ }^{*}$ Significant at 1 and $5 \%$ probability by the $\mathrm{F}$ test, respectively; ${ }^{\mathrm{NS}}$ - not significant at $5 \%$ probability by the $\mathrm{F}$ test. 
farming to Ultisol for 120 days, and similarly found that $\mathrm{pH}$ and $\mathrm{P}$ attributes were little altered by the application of the residue. The study by Coelho et al. (2015a) found a significant effect and a non-significant effect of the percolated landfill dilution on $\mathrm{K}+$ and $\mathrm{OM}$ attributes, respectively, partially corroborating the results of the present study.

In analyzing the contrasts of $\mathrm{pH}, \mathrm{OM}, \mathrm{P}$ and $\mathrm{K}^{+}$attributes, only the $\mathrm{C} 2$ orthogonal contrast showed significance at $1 \%$ probability, meaning that the $\mathrm{T} 4$ treatment presented greater accumulation of $\mathrm{P}$ in the soil in relation to the other treatments. The absorption and the availability of $\mathrm{P}$ in the plants is correlated with $\mathrm{OM}, \mathrm{pH}$ and the degree of soil development, in addition to cation content, which may have been the cause for changes in the $\mathrm{P}$ concentration for the $\mathrm{C} 2$ contrast (Novais et al., 2007).

By comparing the results from Table 3 with those from Table 1, prior to applying the dairy effluent dilutions, it can be pointed out that:

i) Mean $\mathrm{pH}$ values were slightly altered in all treatments, even when the soil received the application of dairy effluent dilutions with alkaline $\mathrm{pH}$ (Table 2), since the studied soil is highly buffered, thus corroborating with Bolzani et al. (2012) who applied doses of pig farming effluent to Ultisol;

ii) ECss increased by $73 \%$ in treatment $\mathrm{T} 5$ as a result of salt accumulation provided by the effluent, and reduced $47,29,3$ and $3 \%$ in $\mathrm{T} 1, \mathrm{~T} 2, \mathrm{~T} 3$ and $\mathrm{T} 4$ treatments, respectively, as a result of salt leaching that occurred throughout the experimental period. Similar results were presented by Coelho et al. (2015a) in their study with percolated landfill dilutions applied to Ultisol;

iiii) OM levels presented reductions of $61,53,65,69$ and $52 \%$ in T1, T2, T3, T4 and $\mathrm{T} 5$ treatments, respectively, even with the $\mathrm{OM}$ provided by the effluent dilutions (Table 2), probably due to an intensification of the mineralization process by bacteria and fungi that decompose OM in inorganic matter on irrigated soil. The study by Coelho et al. (2015a) found an increase in $\mathrm{OM}$ in the soil irrigated with percolated landfill dilutions in relation to the initial experiment condition; iv) $\mathrm{P}$ concentrations presented increases of $14,4,19$ and $82 \%$ in T1, T2, T3 and T4 treatments, respectively, due to the $\mathrm{P}$ contributions provided by the effluent (Table 2), while a $5 \%$ reduction of $\mathrm{P}$ in the soil was observed in $\mathrm{T} 5$ treatments, probably due to the interaction between $\mathrm{P}$ and the salinity reported by Oliveira et al. (2014); and

v) $\mathrm{K}^{+}$showed an increase of $8,29,38,53$ and $72 \%$ in T1, T2, T3, T4 and T5 treatments, respectively, due to the increase of $\mathrm{K}^{+}$in the soil, both by the application of the effluent and public supply water (Table 2), corroborating the study by Coelho et al. (2015a) that applied percolated landfill dilutions to Ultisol.

Figure 2 shows the mean values for the attributes $\mathrm{pH}$, ECss, $\mathrm{OM}, \mathrm{P}$ and $\mathrm{K}$ in the 0 to $0.10 \mathrm{~m}, 0.10$ to $0.20 \mathrm{~m}$, 0.20 to $0.30 \mathrm{~m}, 0.30$ to $0.40 \mathrm{~m}$ and 0.40 to $0.50 \mathrm{~m}$ layers of Ultisol irrigated with dairy effluent dilutions for 240 days.

Figure $2 \mathrm{a}$ shows that mean $\mathrm{pH}$ values for all treatments in the 0 to 0.10 m layer increased in relation to $\mathrm{T} 1$ due to the bicarbonate present in the dairy effluent (Table 2). In general, there was a tendency for $\mathrm{pH}$ to decrease along the soil profile; the oscillations are attributed to salt leaching and to variations in clay content in each soil layer, which probably interfered with salt absorption (Table 1). These results do not corroborate those presented by Lima et al. (2013), in which dairy effluent application to Ultisol for five years increased the $\mathrm{pH}$ of all studied soil layers due to the increase in salts.

The mean $\mathrm{pH}$ varied between 6.2 and 7.4 , and thus according to Ribeiro et al. (1999) it can be classified as low alkalinity acid. According to Novais et al. (2007), pH between 6.0 and 6.5 are considered as optimal, in which maximum macronutrient availability occurs, in addition to limiting the availability of heavy metals present in the soil.

An increase of ECss along the soil profile was observed for treatments $\mathrm{T} 3$, T4 and T5, also due to leaching and accumulation of salts in the higher clay content layers (Table 1). These results differ from those obtained by Coelho et al. (2015a) by the application of percolating landfill dilutions in the 0 to $0.20 \mathrm{~m}$ and 0.20 to $0.40 \mathrm{~m}$ layers of an Ultisol for 120 days, in which the ECss values of the treatments that used 
$\mathbf{A}$

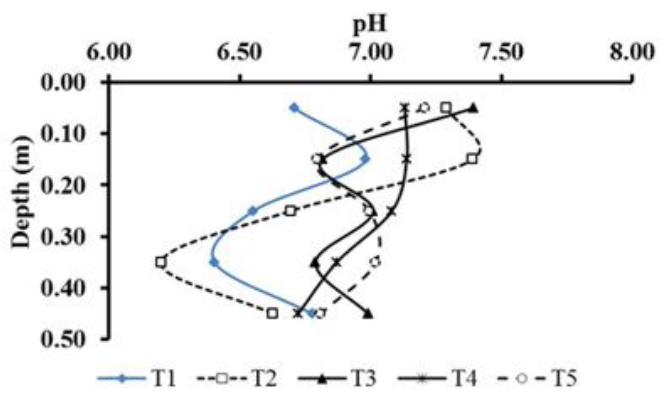

C

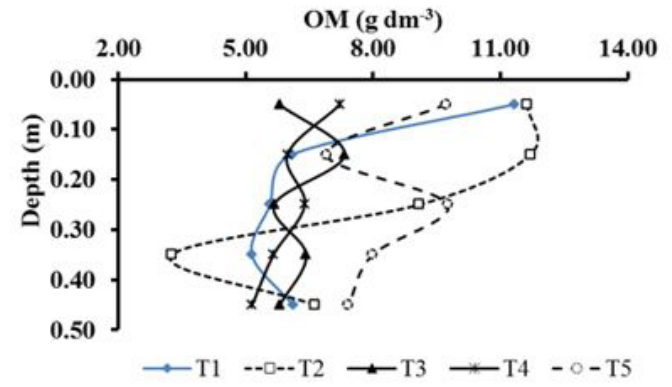

B

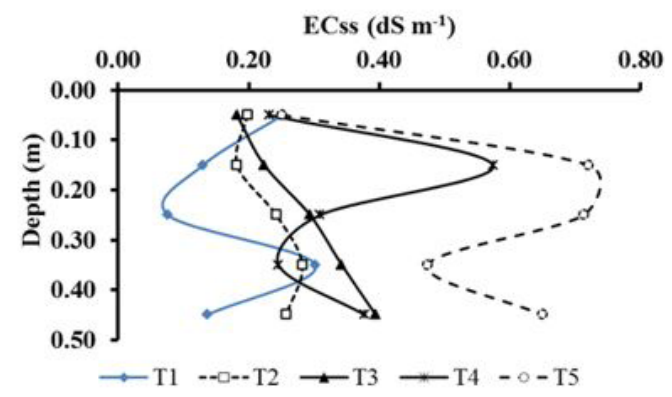

D

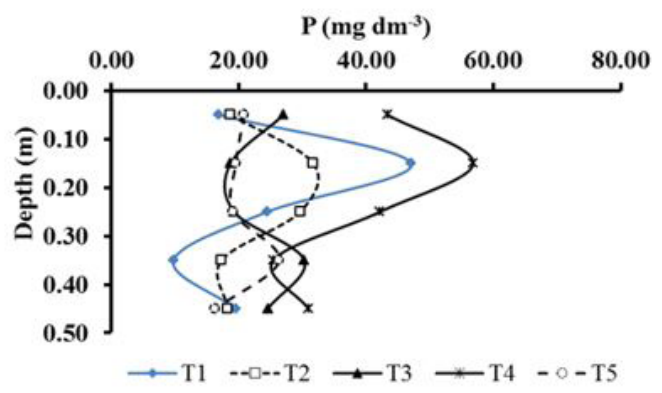

$\mathbf{E}$

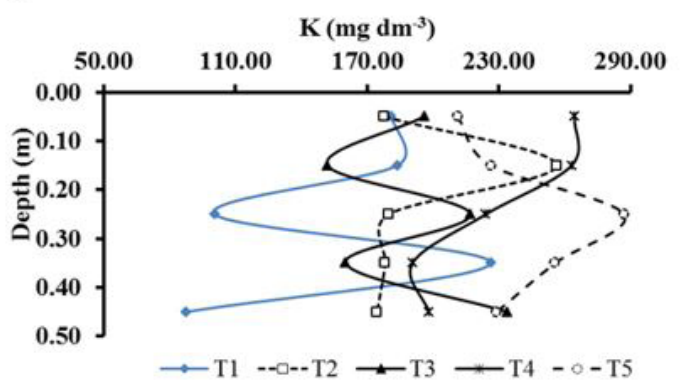

Figure 2. Behavior of $\mathrm{pH}, \mathrm{ECss}, \mathrm{OM}, \mathrm{P}$ and $\mathrm{K}$ at five depths of an Ultisol irrigated with dairy effluent proportions in the public water supply for 240 days.

the effluent were higher than ECss for the treatment irrigated with only public water supply.

The salt concentration in the root zone can increase progressively, unless leaching and drainage reduce soil surface content, as seen in the study profile. NSW (2010) describes that soil salinity causes impact in some areas of reuse, mainly in the root zones, affecting the yield of sensitive crops at high salt concentrations.

OM levels in the treatments varied, with $\mathrm{T} 2$ and $\mathrm{T} 5$ showing the highest increases (Figure 2C). In T2, the highest $\mathrm{OM}$ increases occurred in the layers of 0.10 to $0.20 \mathrm{~m}$ and of 0.20 to $0.30 \mathrm{~m}$, while in T5 these increases occurred in the layers of 0.20 to $0.30 \mathrm{~m}$, 0.30 to $0.40 \mathrm{~m}$ and 0.40 to $0.50 \mathrm{~m}$, probably due to the lower mineralization of $\mathrm{OM}$ in these treatments, and to the contribution of $\mathrm{Cl}^{-}$provided by the effluent (Table 2) which can interfere with the diversity, survival and activity of OM decomposing microorganisms, as chlorine is a bactericidal agent. These results differ from those presented by Coelho et al. (2015a), that observed higher values of $\mathrm{OM}$ and always in the superficial layer ( 0 to $0.20 \mathrm{~m}$ ); in addition, they showed that the $\mathrm{OM}$ content from treatments that received the percolating landfill application were generally smaller in relation to the treatment irrigated with only public water supply. 
According to Ribeiro et al. (1999), the OM contents from the superficial layer in treatments T1, T2, T4 and T5 were classified as low $\left(7.1 \mathrm{~g} \mathrm{~kg}^{-1}<\mathrm{OM}<20.0 \mathrm{~g} \mathrm{~kg}^{-1}\right)$, while T3 received a very low score $\left(<7.0 \mathrm{~g} \mathrm{~kg}^{-1}\right)$. These results differ from those presented by Coelho et al. (2015a), who classified the 0 to $0.20 \mathrm{~m}$ and 0.20 to $0.40 \mathrm{~m}$ OM layers of this same soil only being low in the year 2012 .

Figure 2D shows that the highest $\mathrm{P}$ supply to the soil by dairy effluent occurred in the T4 treatment, mainly in the 0.10 to $0.20 \mathrm{~m}$ layer due to the leaching process of the organic fraction of $\mathrm{P}$, and to the greater contribution of $\mathrm{OM}$ and the lower clay content in the 0 to $0.10 \mathrm{~m}$ and 0 to $0.20 \mathrm{~m}$ layers before application of dairy effluent dilutions (Table 1). These results differ from those found by Oliveira et al. (2014) in a study of Ultisol irrigated with dairy effluent for 5 years, where the maximum phosphorus concentration was detected in the 0 to $0.10 \mathrm{~m}$ layer due to the higher concentration of OM increased by grass cultivation. According to Ribeiro et al. (1999), inorganic P barely moves in most soils, especially in clay soils due to the adsorption and precipitation of the element with the other soil constituents.

According to the clay content from Table 1 and $\mathrm{P}$ values from Figure 2D, $\mathrm{P}$ was classified as low $\left(6.7 \mathrm{mg} \mathrm{dm}^{-3}<\mathrm{P}<12.0 \mathrm{mg} \mathrm{dm}^{-3}\right.$ and $0.15 \mathrm{~kg} \mathrm{~kg}^{-1}<$ clay $\left.<0.35 \mathrm{~kg} \mathrm{~kg}^{-1}\right)$ and very good $\left(\mathrm{P}>45.0 \mathrm{mg} \mathrm{dm}^{-3}\right.$ and $0 \mathrm{~kg} \mathrm{~kg}^{-1}<$ clay $\left.<0.15 \mathrm{~kg} \mathrm{~kg}^{-1}\right)$, as proposed by Ribeiro et al. (1999).

It is worth mentioning that high $\mathrm{P}$ levels in the soil can cause pollution in surface and underground waters carried by runoff and soil erosion processes. Soil erosion and crop removal are the main forms of losing P from the soil. Leaching through the soil profile does not occur in short or medium terms, and it is necessary to prepare a mass balance for $\mathrm{P}$ on an annual basis or from three to five years (NSW, 2010).

By analyzing Figure $2 \mathrm{E}$ it was observed that $\mathrm{K}^{+}$was emphasized in the superficial layer of T4, standing out among the other treatments, but reducing its content in depth. However, T5 had the maximum value for the 0.20 to $0.30 \mathrm{~m}$ layer due to the leaching process and the higher contribution of $\mathrm{K}$ from the dairy effluent. These results do not corroborate those found by Coelho et al. (2015a), who observed increased $\mathrm{K}$ in the 0 to 0.20 and 0.20 to $0.40 \mathrm{~m}$ layers of the treatments that received percolated landfill dilutions, while the treatment irrigated with only public water supply had the lowest $\mathrm{K}$ values. In the study by Lima et al. (2013) where Ultisol was irrigated with dairy effluent for five years, a reduction of $\mathrm{K}^{+}$was evidenced throughout the studied profile, with maximum values for the surface and minimum for the 0.40 and $0.50 \mathrm{~m}$ layer.

According to Ribeiro et al. (1999), K contents were classified as very good $\left(\mathrm{K}>120 \mathrm{mg} \mathrm{dm}^{-3}\right)$ among all treatments, specifically for the 0 to 0.10 and 0.10 to $0.20 \mathrm{~m}$ layers. These authors also report that $\mathrm{K}$ can significantly be displaced in soils with low cation exchange capacity, moving vertically and laterally, even in clay soils. Thus, application in installments throughout the crop cycle is recommended.

\section{CONCLUSIONS}

No significant effects of dairy effluent dilutions were found in altering $\mathrm{pH}$, organic matter or potassium of Ultisol values after 240 days of application.

The analysis by orthogonal contrasts revealed a significant increase of phosphorus in the T4 treatment (30\% of the United States Environmental Protection Agency-EPA dosage criterion for dairy effluent plus public water supply-PWS).

The electrical conductivity of the soil saturation extract was significantly altered by the dairy effluent dilutions, increasing salts mainly in the 0.10 to $0.20 \mathrm{~m}$ layer of the T5 treatment ( $40 \%$ of the EPA dosage for dairy effluent plus PWS).

\section{ACKNOWLEDGEMENTS}

FINEP, CNPq and CAPES for financial support.

\section{SUBMISSION STATUS}

Received: 10 june, 2017

Accepted: 13 sep., 2017

\section{CORRESPONDENCE TO}

\section{Rafael Oliveira Batista}

Departamento de Engenharia e Ciências

Ambientais, Universidade Federal Rural do

Semi-Arido - UFERSA, Av. Francisco Mota, 572,

Bairro Costa e Silva, CEP 59625-900, Mossoró,

$\mathrm{RN}$, Brasil

e-mail: rafaelbatista@ufersa.edu.br 


\section{FINANCIAL SUPPORT}

\section{FINEP, CNPq and CAPES}

\section{REFERENCES}

Alvares CA, Stape JL, Sentelhas PC, Gonçalves JLM, Sparovek G. Koppen's climate classification map for Brazil. Meteorologische Zeitschrift 2014; 22(6): 711-728. http:// dx.doi.org/10.1127/0941-2948/2013/0507.

Bolzani HR, Oliveira DLA, Lautenschlager SR. Efeito da aplicação de água residuária de suinocultura no solo e na qualidade dos seus lixiviados. Engenharia Sanitaria e Ambiental 2012; 17(4):385-392. http://dx.doi.org/10.1590/ S1413-41522012000400005.

Cavalcanti NB, Resende GM. Efeito de diferentes substratos no desenvolvimento do mandacaru sem espinhos (Cereus hildemannianus K. Schum). Caatinga 2006; 19(3): 255-260.

Chaiudhari DH, Dhoble RM. Performance evaluation of effluent treatment plant of dairy industry. Current World Environment 2010; 5(2): 373-378. http://dx.doi. org/10.12944/CWE.5.2.26

Coelho DCL, Batista RO, Oliveira AFM, Silva KB. Alterações químicas de Argissolo irrigado com percolado de aterro sanitário e água de abastecimento. Revista Brasileira de Engenharia Agrícola e Ambiental 2015a; 19(6): 598-604. http://dx.doi.org/10.1590/1807-1929/ agriambi.v19n6p598-604.

Coelho DCL, Batista RO, Silva PCM, Mesquita FO. Produção de capim elefante utilizando percolado de aterro sanitário. Bioscience Journal 2015b; 31(3): 830-840. http:// dx.doi.org/10.14393/BJ-v31n3a2015-22400.

DairyCatch. Environmental best practice guidelines: effluent management. Australia: DAFWA; 2006.

Demirel B, Yenigun O, Onay TT. Anaerobic treatment of dairy wastewaters: a review. Process Biochemistry 2005; 40(8): 2583-2595. http://dx.doi.org/10.1016/j. procbio.2004.12.015.

Empresa Brasileira de Pesquisa Agropecuária - EMBRAPA. Sistema brasileiro de classificação de solos. 3. ed. Brasília: Embrapa Solos; 2013.

Environmental Protection Agency - EPA. Process design manual: land treatment of municipal wastewater. Washington: Department of the Interior; 1981.

Farizoglu B, Uzuner S. The investigation of dairy industry wastewater treatment in a biological high performance membrane system. Biochemical Engineering Journal 2011; 57(1): 46-54. http://dx.doi.org/10.1016/j.bej.2011.08.007.

Ferreira DF. Sisvar: A computer statistical analysis system. Ciência e Agrotecnologia 2011; 35(6): 1039-1042. http:// dx.doi.org/10.1590/S1413-70542011000600001.
Lima VIA, Alvez SMC, Oliveira JF, Batista RO, Pinheiro JG, Di Souza L. Desempenho do sistema de tratamento de água residuária de laticínios e os efeitos de sua disposição em Argissolo. Water Resources and Irrigation Management 2013; 2(2): 93-101.

Marques BCD, Cunha VT, Cunha VT, Silva KB, Batista RO. Desempenho de gotejadores operando com água residuária de laticínios em escala laboratorial. Irriga 2016; 21(1): 140-155

Matos AT, Abrahão SS, Lo Monaco PAV, Sarmento AP, Matos MP. Capacidade extratora de plantas em sistemas alagados utilizados no tratamento de águas residuárias de laticínios. Revista Brasileira de Engenharia Agrícola e Ambiental 2010; 14(12): 1311-1317. http://dx.doi. org/10.1590/S1415-43662010001200009.

Mohammad Rusan MJ, Hinnawi S, Rousan L. Long term effect of wastewater irrigation of forage crops on soil and plant quality parameters. Desalination 2007; 215(1-3): 143-152. http://dx.doi.org/10.1016/j.desal.2006.10.032.

New South Wales Government - NSW. Effluent reuse management. Australia: Department of Environment and Climate Change and Water; 2010.

Novais RF, Alvarez V VH, Barros NF, Fontes RLF, Cantarutti RB, Neves JCL. Fertilidade do solo. Viçosa: SBCS; 2007.

Oliveira JF, Alves SMC, Batista RO, Lima VI, Di Souza L. Avaliação de sistema de tratamento de laticínio e o efeito do efluente gerado nos atributos físico-químico de um argissolo vermelho. Engenharia na Agricultura 2014; 22(1): 58-66. http://dx.doi.org/10.13083/1414-3984.v22n01a07.

Qasim W, Mane AV. Characterization and treatment of selected food industrial effluents by coagulation and adsorption techniques. Water Resources and Industry 2013; 4: 1-12. http://dx.doi.org/10.1016/j.wri.2013.09.005.

Ribeiro AC, Guimarães PTG, Alvarez VH. Recomendações para o uso de corretivos e fertilizantes em Minas Gerais. Viçosa: CFSEMG; 1999.

Santos PM, Santos AC, Silva JEC. Resíduo de laticínio em pastagem de capim Mombaça: atributos químicos da forragem e do solo. Semina: Ciências Agrárias 2013; 34(1): 377-390. http://dx.doi.org/10.5433/1679-0359.2013v34n1p377.

Sarkar B, Chakrabarti PP, Vijaykumar A, Kale V. Wastewater treatment in dairy industries - possibility of reuse. Desalination 2006; 195(1-3): 141-152. http://dx.doi. org/10.1016/j.desal.2005.11.015.

Silva FC. Manual de análises químicas de solos, plantas e fertilizantes. 2. ed. Brasília: Embrapa Informação Tecnológica; 2009.

Toze S. Reuse of effluent water - benefits and risks. Agricultural Water Management 2006; 80(1-3): 147-159. http://dx.doi.org/10.1016/j.agwat.2005.07.010. 